DOI: $10.1515 / \mathrm{rpp}-2017-0005$

Doctor of Pedagogical Sciences, Associate Professor, IHOR KANKOVSKY

Khmelnytskyi National University

Doctor of Pedagogical Sciences, Associate Professor, HANNA KRASYLNYKOVA

Khmelnytskyi National University

Address: 11 Instytutska St., Khmelnytskyi, 29016, Ukraine

E-mail:krasil@ukr.net

Postgraduate Student, IRYNA DROZICH

Khmelnytskyi National University

Address: 11 Instytutska St., Khmelnytskyi, 29016, Ukraine

E-mail: irina.drozich@ukr.net

\title{
COMPARATIVE ANALYSIS OF FUTURE COOKS' TRAINING IN VOCATIONAL INSTITUTIONS IN UKRAINE AND ABROAD
}

\begin{abstract}
The article deals with comparative analysis of conceptual approaches and content of cooks' training in Ukraine, European countries, the USA and Eastern Partnership countries. It has been found out that national vocational education is grounded on education standards and activity-based approach to forming the training content, subject-based structure of curricula and, surely, needs to become competency-based. It has been revealed that in Eastern Partnership countries there is a normative base of cooks' vocational training and it is accorded with the competency-based approach. However, such states as the Russian Federation, the Republic of Belarus, the Republic of Kazakhstan implement study programs for training cooks in traditional institutions of formal vocational training of Post-Soviet type. At the same time, the training of future cooks in European countries is mainly oriented toward the concept of continuing education and is variable, multilevel, wide-profile, at most approximated to the needs of catering trade. The level-based curricula and dual system of cooks' training in vocational schools of France, Austria and Italy have been characterized. In addition, the authors have defined the common feature of professional practical training of cooks in culinary schools in the USA, that is its organization under the conditions of real production that ensures a wide professional competency of future cooks, their acquiring knowledge and skills needed for professional activity. It has been concluded that positive aspects of foreign experience may assist in defining prognostic directions for the development of cooks' vocational training in Ukraine.

Key words: cook, vocational training of cooks, conceptual approach to training specialists, competency-based approach, dual system, vocational institution, vocational schools, foreign experience.
\end{abstract}

\section{INTRODUCTION}

Today, catering trade plays an important role in modern society as nutrition meets vital needs of people and is one of the main components of their existence. The efficiency of modern catering establishments is based on the implementation of many new services 
and products. Thus, service culture and competitiveness of the mentioned establishments is closely connected with profound vocational training of catering specialists.

One of the most popular and prestigious professions of catering training all over the world is cooking. No wonder, since the monthly wages of highly skilled cooks in the $\mathrm{EU}$ is about $\$ 4,500$, and the starting salary of a certified cook in the USA is from 15,000 to $\$ 20,000$ per year. Later on, when cooks become owners or co-owners of restaurants, their income increases to $\$ 100,000$ per year (ВОтпуск.ru, 2017).

Under the conditions of Ukraine's intergration in Europe, it is important to approximate educational paradigms, fundamental principles, methodological approaches to designing the content and implementing innovative pedagogical and production technologies to ensure the quality of future catering specialists' training. In this context, top-priority are comparative researches, since it is necessary to search for new forms and methods of cooks' vocational training, including foreign pedagogical experience as well as its creative application.

\section{THE AIM OF THE STUDY}

The aim of the study is to conduct comparative analysis of conceptual approaches and content of future cooks' training in vocational institutions in Ukraine and abroad.

\section{THEORETICAL FRAMEWORK AND RESEARCH METHODS}

The idea of comparative researches is not new in pedagogy. First comparative researches were conducted by such outstanding perdagogues as J. A. Komenský, K. Ushynskyi and L. Tolstoi, who were of the view that borrowing from foreign pedagogy was possible only within individual learning methods and simultaneously categorically opposed to borrowing other's education systems, they indicated that it was necessary to have one's own education system which would correspond to historical and national peculiarities of the people's lives.

Comparative pedagogical aspects in the development of modern foreign systems of vocational education have been studied by such Ukrainian researchers as N. Abashkina (German vocational education), N. Bidyuk (training engineering at British universities), T. Desiatov (continuing education in Eastern European countries), L. Hrynevych (trends in decentralization of basic education regulation in Poland), A. Kaplun (agricultural vocational schools in Poland), N. Nychkalo (vocational education and training in the European Union), V. Parzhnytskyi (training of skilled workers for machine-building in post-socialist and European countries), S. Sysoieva (continuing vocational education in the documents of the European Union), S. Zaskalieta (agricultural training in the European Union) and others. The problem of cooks' training in vocational education institutions abroad has not been the subject of scientific researches yet.

While researching we have used theoretical and empirical research methods, the study of normative and legal documents, education standards, syllabi that regulate the training of future cooks, Internet resources, practical experience of vocational education institutions abroad to single out the approaches and directions of their implementation in vocational education in Ukraine.

\section{RESULTS}

At the beginning of the $21^{\text {st }}$ century a group of researchers and practitioners from Ukraine led by V. Radkevych started working on a new concept of future cooks' training. After being publicly discussed and approved it became the basis of the State Standard of Vocational Education (DSPTO-5122-NO.55.3.5-2007) for Training Cooks of Categories 3-6 (Міністерство освіти і науки України, 2007). 
This standard set the duration of cooks' training in vocational education institutions of first certification level, namely, the 3rd category is equal to 894 hours, the 4th category 1085 hours, the 5 th level -700 hours, the 6th category -460 hours.

Vocational education institutions, enterprises, establishments and organizations engaged in training cooks were given the right to determine a variable component of the content of vocational education curricula (up to $20 \%$ within total time) and syllabi (up to $20 \%$ of time for mastering subjects and industrial training) in accordance with the changes in technical devices, technology, labour organization.

The content of future cooks' vocational training (categories 3-6) is divided into general and vocational, vocational and theoretical, vocational and practical training. General and vocational training provided for introducing students to information technologies, the basics of legal knowledge, industrial economics and business and traffic rules and regulations. The part of training time allotted for training realization was left in reserve to respond to labour market needs and study specific subjects (Job Search Techniques, Business Ethics and Communication Culture, Production Design etc.).

Vocational and theoretical training involved the study of both traditional special subjects such as Cooking Technologies and new ones such as Standardization and Certification in Catering Trade, Methods of Quality Control and Management in Catering Trade, Peculiarities of Foreign Services Sector, Foreign Language for Specific Purposes (FLSP). The structure of vocational and practical training combined industrial learning, industrial practice and art workshops.

So, it is obvious that national vocational training of cooks based on the current State Standard of Vocational Education (DSPTO-5122-NO.55.3.5-2007), activity-based approach to forming the training content and subject-based structure of curricula needs to become competency-based. It should be mentioned that in order to update the content of vocational education in 2016-2017 the Ministry of Education and Science of Ukraine started to develop the draft of the State Standard of Vocational Education for Training Cooks grounded on the competency-based approach (Інститут професійних кваліфікацій, 2015).

Regarding foreign experience, its characteristics, in our opinion, should be introduced in the following order:

- training of future cooks in vocational education institutions in Eastern Partnership countries (the Russian Federation, the Republic of Belarus, the Republic of Kazakhstan), based on the tradition of post-Soviet vocational school;

- training of cooks in European vocational schools (France, Austria, Italy) and American culinary schools that is rather different;

Unlike native approaches to training future cooks, Russian scholars adhere to a slightly different concept. Its main provisions were included into the Federal State Standard of Secondary Vocational Education No 260807.01 for training cooks-confectioners that was approved in 2013 (Информационно-правовой портал Гарант, 2013), and grounded on a competencey-based approach. Training results can be assessed by specialists' mastering general and professional competences. General competences combine the ability to understand the nature and social significance of future profession, to show stable interest in it; to organize one's own activity based on goals and ways for its realization defined by the supervisor; to analyze working situations, evaluate and adjust one's own activity; to use information and communication technologies in professional activity; to work in team, effectively communicate with colleagues, administration, customers etc. Professional 
competences correspond to activities of cooks-confectioners and provide for readiness for primary processing raw materials and preparing appropriate dishes, snacks, drinks as well as bakery, floury and confectionery products.

Accordingly, the content of future cooks and confectioners' vocational training in Russian vocational education institutions should include two training cycles: general and vocational, vocational and various types of practices. The compulsory part of training content is equal to $80 \%$ of total training time. The variable part (about $20 \%$ ) provides the possibility of its expansion and (or) complication to gain more competences in accordance with the needs of labour market, to improve graduates' competitiveness. It must be noted that the new concept of cooks and confectioners' training in the Russian Federation did not limit education institutions' freedom of choice of education priorities in the training content and, therefore, provided the opportunity for their creative implementation.

In the Republic of Belarus cooks (categories 3-4) are trained in accordance with the State Standard of Vocational Education (3-91 0151 Public Catering) (Национальный правовой Интернет-портал Республики Беларусь, 2016). The standard sets the following duration of future cooks' training: 2 years and 6 months - based on general basic education and 1 year - based on secondary education.

A typical curriculum for future catering specialists' training includes such components as general and vocational, vocational, monitoring, counseling, extracurricular activities. A general and vocational component consists of social and humanitarian, natural and mathematical cycles as well as a range of subjects such as Physical Education and Health and additional training time. A vocational component includes general and vocational and special cycles, additional training time and a variable part. Industrial training and practice are given not less than $40 \%$ of the total amount of training hours in vocational education curricula. It should be mentioned that education institutions may add hours for industrial training by reducing the amount of hours needed to study subjects of the vocational component.

In the Republic of Belarus future catering specialists must have a range of professional competences, including carying out culinary processing of raw materials; cooking for different categories of population at various catering enterprises; complying with sanitary regulations on food preservation, personal hygiene; understanding the main economic categories and concepts; the knowledge of foreign languages (speaking minimum) etc.

The Republic of Kazakhstan has its own original concept of future cooks' training. The duration of training is 2 years and 10 months - based on basic secondary education and 1 year and 10 months - based on general secondary education (Интернет-журнал «Просвещение», 2015).

The content of future cooks' training provides for normative and variable parts. The compulsory content of cooks' training is conventionally divided into three cycles of subjects: humanities, general vocational, special. The cycle of optional disciplines determined by the education institution aims to meet the employers' requirements and provide the opportunity to supplement the training content taking into account the accumulated experience of the teaching staff.

The amount of hours for this training cycle can be increased up to $25 \%$ by reducing those hours allotted for general vocational and special subjects. According to the standard, practical skills and abilities of future cooks are formed during introductory and training (180 hours), technological (1080 hours) and industrial (540 hours) practices. 
So, vocational training of cooks in Russia, Belarus and Kazakhstan is grounded on the national standards of vocational education adopted by these countries as well as the competency-based approach. This allows to solve important practical tasks, to analyze industrial processes, to predict technical and technological changes in labour sector, to produce reliable criteria for training results assessment. Such a conceptual approach to training future cooks increases their social activities, professional mobility and competitiveness.

We would like to analyze European experience in training cooks. Vocational training of cooks in France is mostly carried out in vocational schools. Hospitality School headed by Jean Drouant in Paris resembles our vocational school. A two-year program is targeted at ninth-graders without admission exams, and after its completion they receive a diploma which gives them the right to be assistant cooks.

During training pupils undergo a 12-week internship. After a three-year training students receive the following specialties: cooking, rerstaurant service, room service. After successfully completing this course, students will obtain a so-called "technological leaving certificate". Those who wish to continue their learning, may choose one of the specialties mentioned above and study two more years. During the next two years students undergo a 5-month internship that is based on the chosen specialty: in a hotel, restaurant hall, kitchen. The internship takes place in Paris or abroad, for example, in the USA, if student has a command of the English language.

While studying students master economics, marketing, management, foreign languages (English, Spanish, German). There are 8 kitchens, 3 confectionary departments, a restaurant within the school. Up to 12 students can work in each kitchen. Training is completed after the exams have been taken. Those pupils who successfully have passed the exam obtain a diploma and may work as mid-level cooks. Thus, after completing the training young specialists (20-22 years old) possess practically a full spectrum of activities in the hotel and restaurant business as they know how to plan a menu, all the peculiarities of cooking, customer services etc. (Мумрикова, 2001).

One of the oldest French culinary schools is considered to be Le Cordon Bleu, founded in 1895 in Paris. The training lasts from 3 to 9 months and can start from any level of training. Experienced cooks attend a 12-week course of general cooking, beginners - a 36-week course.

Classrooms are equipped with modern technical devices, lectures are conducted in French being simultaneously translated into English. During workshops students can examine the process of cooking from all the sides using rear-view mirrors. Headcook explains cooking techniques and demonstrates the sequence of their preparation. At the end of workshops students can degust dishes that helps them to develop their taste and master skills of setting and presenting dishes.

In Le Cordon Bleu curricula are divided into three levels: elementary, intermediate and high. At the elementary level (162 hours) students gain basic knowledge of traditional culinary technology, namely, study culinary terms and definitions, food processing and preservation methods, food history, production hygiene and sanitation, production organization, equipment, occupational safety, sauce, pastry and forcemeat cooking technology.

From the first day of training the obtained knowledge is strengthened due to practical training in the kitchen. Students are divided into groups of 12-14 people so that they may practice their cooking skills, work with equipment and tools. At the end of 
workshops teacher tastes dishes and assesses students' work. The criteria for assessment are organoleptic properties of dish (taste, smell, consistency, appearance) and preparation time.

The intermediate level (147 hours) involves studying characteristics of food products, their origin, classic technologies of French and other cuisines all over the the world. At the same time, main attention is paid to the ratio of colour, shape, size of products and ready meals as well as their organoleptic characteristics.

According to high level programs (202 hours) students study original and modern interpretations of classic dishes, the most difficult cooking techniques as well as the combination of various components in dishes. Also students are given the opportunity to be creative and prepare their own dishes. At the final stage of training future cooks take the final exam, namely, they are to prepare a dish in a specified period of time. After obtaining a diploma of a qualified cook, students may work as cooks, teachers, counselors in catering trade (Le Cordon Bleu, 2017). In addition to culinary schools one can study cooking in Hotel and Tourism Management Academy, where classes imitate restaurant kitchen. Academie Internationale Maxim's de Paris is considerably recognized, too (Maxim's de Paris, 2017).

According to the resolution of the Federal Ministry for Economics and Labour, vocational schools for catering and hotel industry in Vienna provide a 3-year training for future cooks. The duration of training is equal to 1080 hours as it is defined in the curriculum. Programs include various aspects of cooking technologies, using catering equipment, nutrition physiology, sanitation and hygiene.

In Austria future cooks master compulsory and optional subjects. Compulsory subjects include Political Education (80 hours), Germany and Communications (100- 140 hours), Professional Language (40-100 hours), Second Professional Foreign Language (80 hours), Accounting and Economics (180 hours), Dietology ( 80 hours), Food and Menu (120 hours), Organization and Tourism ( 80 hours), Practical Activities (320 hours). Students may choose the following optional subjects: Religious Studies, Modern Foreign Language, Physical Education, Winemaking, Creative Cooking. Industrial training is carried out under the conditions of industrial environment (Berufsschule für Gastgewerbe, 2017).

One of the leading culinary schools in Italy is Italian Culinary Institute for Foreigners. Seminars and workshops are conducted by well-known restaurant critics and chefs. Classes are devoted not only to cooking, but also Italian history, culture, language - everything that is connected with food and wines. The program is divided into two parts: first two months students study theory in a picteresque castle of Asti, next four months they apply the obtained knowledge in the best restaurants of Italy. After successfully completing the program, students obtain a diploma. Those who have not passed exams receive certificates of participation in the program (Italian Culinary Institute for Foreigners, 2017).

Therefore, the conducted analysis of European experience shows that future cooks' training in France, Austria, Italy is carried out on the basis of the dual training system. According to this system, students simultaneously gain theoretical knowledge within the education institution (1-2 days per week) and practical skills while being in the industry (3-4 days per week). The dual training system is aimed at orienting students toward vocational training that provides the qualification and competences needed in practice in a changing world (Hippach-Schneider, Krause, Woll, 2007). Within the dual training system the structure of future cooks' vocational training in European countries is characterized by heterogeneity and complexity. 
However, most culinary schools are located in the USA as culinary industry is one of the most powerful in this country, and as of 2014 it provided employment for about 13.5 million workers (National Restaurant Association, 2017).

In the USA culinary education can be obtained on the basis of public schools that offer vocational training called Career and Technical Education. The concept of cooks' vocational training includes courses and special courses that allow students to prepare for professional cooking. Training lasts at least two years of secondary and two years of vocational education, after which graduates are given a professional certificate or awarded a degree of junior expert in cooking. Almost half the secondary schools in the country offer such vocational programs.

Post secondary trade schools offer education for elder students who want to develop or change their careers. The duration of training is typically 2 years and mostly depends on the peculiarities of the education institution, curricula and programs. Curricula include practical and theoretical components. According to 2-year programs, students acquire basic knowledge and skills related to food safety, sanitation and hygiene, cooking technology, menu planning and others. The content of 4-year programs is supplemented with themes connected with cooking the large number of servings, specialized cooking techniques, cooking regional and national cuisines etc. The critical factor is that an internship is an integral part of the program's practical component. Some culinary schools and programs provide for a paid internship (Trade School, Colleges and Universities, 2017).

The Dorsey Culinary Academy in Michigan developed an annual program of training cooks. Students study the following subjects: Culinary Arts Basics, Nutrition Basics, Specialties, Regional and International Cuisine, Service in Catering Trade. Practical training takes place in local cafes, restaurants as well as under the conditions of real industrial environment. After completing the program, students take an exam and receive a certificate (Dorsey Schools, 2017)

Thus, the advantages of programs in American culinary schools are the flexibility of internal structural modules that allows to teach students taking into account the latest scientific and technological achievememts as well as the interdisciplinary approach to acquiring knowledge and writing projects that emerged as a result of allowing students to choose subjects to their liking (within the required minimum of credit points / passes). The common feature of cooks' vocational and practical training in European countries and the USA is its organization not in the education institution, but in modern restaurants, bars and cafes, namely, under the conditions of real industrial environment. Thus, future cooks are provided with extensive vocational competences, knowledge and skills necessary for professional activities. At the same time, this eliminates the main disadvantage in traditional systems of vocational training in postSoviet countries - the difference between theory and practice.

\section{CONCLUSIONS}

The conducted analysis of foreign experience in training future cooks, namely, in European countries and the USA, has proved that it is mainly focused on the concept of continuing vocational education and is variable, multilevel, wide-profile, at most approximated to the needs of catering trade. The orientation of cooks' training toward labour market needs creates high motivation to acquire knowledge and skills and ensures high employment rates of graduates.

It has been revealed that in Eastern Partnership countries (the Russian Federation, the Republic of Belarus, the Republic of Kazakhstan) vocational education is grounded on education standards and the competency-based approach. At the same time, national 
vocational training of cooks based on the curent education standard needs to become competency-based.

So, we can conclude that each country has its peculiarities in the organization of training. We believe it necessary to take into account positive aspects of foreign experience and implement innovative approaches to training specialists in catering as it will enhance the efficiency of cooks' training in national vocational education institutions.

Further scientific researches should be aimed at revealing the ways to succesfully implement positive aspects of foreign experience in practice of national vocational training of cooks.

\section{REFERENCES}

1. Berufsschule für Gastgewerbe [Vocational Schools for Catering and Hotel Industry]. (2017). Koch/Köchin [Male/Female Cook]. Retrieved 19.02.2017 from : http://www.bsgg.at/start/lehrberufe/kochkochin/.

2. Dorsey Schools. (2017). Dorsey Culinary Academy in Michigan. Retrieved 19.02.2017 from : http://www.dorsey.edu/dorsey-culinary-academy/.

3. Hippach-Schneider, U., Krause, M., Woll, K. (2007). Vocational Education and Training in Germany. Short description. Luxembourg : Office for official Publication of the European Communities, $87 \mathrm{p}$.

4. Italian Culinary Institute for Foreigners. (2017). Professional Courses. Retrieved 19.02.2017 from : http://www.icif.com/en/.

5. Le Cordon Bleu. (2017). Cuisine Programmes and Courses. Retrieved 19.02.2017 from : < https://www.cordonbleu.edu/paris/cuisine-programmes/en.

6. Maxim's de Paris [Maxim's of Paris]. (2017). Academie Internationale Maxim's de Paris [Maxim's International Academy of Paris]. Retrieved 19.02.2017 from : http://maxims-de-paris.com/fr/.

7. National Restaurant Association. (2017). Workforce Engagement. Retrieved 19.02.2017 from : http://www.restaurant.org/Home.

8. Trade School, Colleges and Universities. (2017). Culinary Career and Education Overview. Retrieved 19.02.2017 from : http://www.trade-schools.net/culinary/\#article.

9. ВОтпуск.ru [OnHoliday.ru]. (2017). Профессия, которая кормит [The Proffesion that Feeds]. Retrieved 19.02.2017 from : https://www.votpusk.ru/edit/text1.asp?ID=99.

10. Інститут професійних кваліфікацій [Institute of Professional Qualifications]. (2015). Проект професійного стандарту «Кухар» [The Draft of Vocational Standard for Cooking]. Retrieved 19.02.2017 from : http://ipq.org.ua/ua/news/83.

11. Интернет-журнал «Просвещение» [Internet Journal "Prosveshchenie"]. (2015). Типовой учебный план технического и профессионального образования специальности 0508000 - Организачия питания [Typical Syllabus of Vocational Education for 0508000 Nutrition Organization]. Retrieved 19.02.2017 from : http://agartu.com/index.php?newsid=806.

12. Информационно-правовой портал Гарант [Garant Information and Legal Portal]. (2013). Федеральный государственный образовательный стандарт среднего профессионального образования по профессии 260807.01 Повар, кондитер [Federal State Education Standard for Secondary Vocational Training for 260807.01 Cooking and Confectionary]. Retrieved 19.02.2017 from : http://www.garant.ru/products/ipo/prime/ doc/70346158/\#ixzz4YJtmpIOc.

13. Міністерство освіти і науки України [Ministry of Education and Science of Ukraine]. (2007). Державний стандарт професійно-технічної освіти ДСПТО 5122 - 
НО.55.3.5-2007. Професія «Кухар», кваліфікачія: 3, 4, 5, 6 розряди [The State Standard of Vocational Education DSPTO-5122-NO.55.3.5-2007 for Training Cooks of Categories 36]. Retrieved 19.02.2017 from : http:/www.vtec.vn.ua/sites/default/files/page/files/kuhar.pdf.

14. Мумрикова, Г. (2001). Увидеть Париж и... поучиться? [See Paris and ... Learn]. Питание и общество [Nutrition and Society], No 4, pp.15-16 (in Russian).

15. Национальный правовой Интернет-портал Республики Беларусь [National Legal Portal of the Republic of Belarus]. (2016). Образовательный стандарт профессионально-технического образования Республики Беларусь по специальности 3-91 0151 «Общественное питание» [Education Standard of Vocational Education of the Republic of Belarus (3-91 0151 Public Catering)]. Retrieved 19.02.2017 from : http://www.pravo.by/document/?guid=3961\&p0=W21631096p. 